DOI: $10.31168 / 0459-6.30$

\title{
В. Мондрьє (Познань, Польша) \\ История польского «Словаря славянских древностей» за четверть века с момента его создания
}

В 2021 г. исполняется четверть века с момента публикации последнего тома польского «Словаря славянских древностей» в 1996 г. (том 8, выпуск 2). В связи с этим стоит детальнее ознакомиться с этой амбициозной инициативой польских славистов, до сих пор являющейся единственным всеобъемлющим энциклопедическим обзором состояния знаний по истории и культуре древних славян до рубежа XIIXIII вв., т.е. до окончательного формирования славянских государств. Географически издание охватывало как районы, где славяне проживали компактно, так и очаги славянских диаспор, в том числе на других континентах, а именно в Азии и Африке. В докладе будут охарактеризованы условия, в которых создавался словарь, а также проблемы, с которыми на разных этапах работы сталкивался его редакционный коллектив.

История создания «Словаря славянских древностей» восходит к первой конференции Федерации исторических обществ славянских и восточноевропейских государств, которая состоялась в Варшаве 29-29 июня 1927 г. Во время конференции Францишек Буяк, профессор истории Львовского университета им. Яна Казимира, создал и возглавил редакционный комитет. Целью данного комитета являлась подготовка коллективного труда под названием «Словарь славянских древностей» в сотрудничестве с широкой группой польских и зарубежных ученых. Эта инициатива, вызванная необходимостью широкого распространения знаний о славянах, их истории, культуре, обычаях, нравах, языках в Польше и за рубежом, показала глубокие иссле- 
довательские интересы польских славистов в межвоенный период.

Согласно принятой концепции, «Словарю славянских древностей» предстояло стать «масштабной энциклопедией прошлого стран и народов всего славянского региона» (Batowski 1945: 8). Самые выдающиеся специалисты из славянских стран должны были собрать и описать всё, что происходило на славянских землях с доисторических времен до конца Средневековья, в частности развитие духовной и материальной культуры. Кроме того, необходимо было учесть всё, связанное со славянством на территориях, которые соседствовали со славянским регионом, т. е. в Румынии, Греции и Венгрии. В состав редакционного комитета вошли представители славянских стран. Издательство находилось во Львове, а работы фонансировал существовавший в то время в Польше Фонд национальной культуры. К 1933 г. были разработаны словники польский, украинский, чешский, словацкий, болгарский и русский; последние из них составили российские историки-эмигранты из Праги и Югославии. В общей сложности к 1936 г. полный список статей насчитывал около 12 тыс. позиций. Также были определены авторы, которым предстояло написать эти статьи, спланирован объем отдельных статей и разработана техническая концепция.

В 1934 г. был издан пробный выпуск словаря, содержащий 12 статей из разных славянских стран (Słownik 1934). Его представили участникам II Международного конгресса славистов, проходившего 23-30 сентября 1934 г. в Варшаве. С 1 сентября 1933 г. редакционную работу стал вести выдающийся польский историк-славист продессор Хенрик Батовский. В предисловии к пробному выпуску он обратил внимание на многочисленные трудности, с которыми столкнулись создатели словаря. Среди них были несовпадающие взгляды на происхождение и прародину славян, а также принятый Редакционным комитетом принцип, чтобы словарь являлся 
«коллективным трудом ученых всех славянских народов с участием представителей науки соседних народов». Он также выразил надежду, что "дальнейшее развитие Словаря славянских древностей, столь необходимого для науки и культуры, больше не будет остановлено, а пойдет вперед быстрыми шагами, объединяя в единодушном сотрудничестве ученых всех славянских и соседних народов» (Słownik 1934: III). Однако подготовка такого огромного издания, состоящего как минимум из шести томов по тысяче страниц в две колонки в каждом, была не под силу одному человеку. Возникли проблемы, касающиеся своевременной подачи статей авторами и шовинистической позиции сербских и болгарских ученых, выступающих против подготовки статей о спорной территории Македонии учеными другой стороны (Batowski 1954: 612).

Следующей проблемой стала необходимость учитывать результаты работы советских ученых. Без сотрудничества с ними российский материал, который прислали ученыеэмигранты из Праги, а также украинский, полученный от украинских исследователей из Львова, оказался неполным. Ректор Варшавского университета профрессор Влодзимеж Антоневич отправился в Москву для установления контактов. Однако сложившаяся тогда политическая ситуация делала любое сотрудничество невозможным. Во время войны все собранные материалы и списки статей были утеряны. В настоящий момент единственным свидетельством новаторской попытки польских славистов Францишка Буяка и Хенрика Батовского является пробный выпуск словаря, отредактированный ими и опубликованный в 1934 г.

Впрочем, несомненно то, что написание и издание такого масштабного труда превышали возможности польских славистов. Сама концепция написания энциклопедических статей учеными из самых разных стран региона связана была с большими расходами, гонорарами, командировками, перепиской. Всё это вместе с отсутствием связи редакции 
с каким-либо из научных учреждений Советского Союза, а также отсутствием доступа к проводимым там исследованиям обрекали начинание польских славистов на провал (Batowski 1945: 8).

После Второй мировой войны польские слависты вернулись к идее издания словаря. Еще в 1949 г. профессора Тадеуш Лер-Сплавинский и Зигмунт Войцеховский представили свой проект издания. С 1955 г. работа велась во вновь созданном Отделе славяноведения Польской Академии наук, а с 1977 г. — в Институте славяноведения ПАН (современный Институт славистики ПАН). В результате должен был появиться двухтомный труд, содержащий статьи исключительно польских авторов. Такой подход обусловливался новыми политическими условиями, которые сделали международное сотрудничество практически невозможным. Общее количество исследователей, сотрудничающих со «Словарем славянских древностей», превысило 300 человек. После того как в 1958 г. опубликовали пробный выпуск словаря, было решено преобразовать издание в многотомную энциклопедию. В итоге число статей в словаре с дополнениями составило примерно 4500, а в последний том вошли именной и географический указатели. В 1961 г. был опубликован том 1, выпуск 1 (А - Б), положивший начало многолетнему издательскому циклу, закончившемуся только в 1996 г., т. е. через 35 лет, публикацией тома 8, выпуска 2 «Словаря». Создавала его небольшая группа сотрудников редакции, которым из-за отсутствия польских исследователей пришлось не только выполнять типичную редакционную работу но и специализироваться в таких областях, как русистика или балканистика ${ }^{1}$. Для облегчения редакционной работы была

1 На первом этапе редакционной работой руководили профессора Юзефр Матушевский и Михал Щанецкий, в 1952-1954 гг. — профессора Юзеф Гайек и Владслав Коваленко, в 1961-1974 гг. — професор Жерар Лабуда, с 1974 по 1984 г. — профрессор Антони Госиоровский, а с 1984 по 1996 г. - профрессор Анджей Вендзкий. 
создана славистическая библиотека, насчитывающая около 40 тыс. томов, в том числе несколько десятков зарубежных славистических журналов.

Концепция инициаторов «Словаря» заключалась в создании междисциплинарного издания, что по тем временам было большим новшеством. Кроме основных дисциплин, таких как история, археология и лингвистика, оно также включало право, антропологию, этнографию, литературу и историю искусства. Впрочем, не удалось учесть результаты исследований по естественным наукам, которые, особенно в последние годы работы над словарем, внесли значительный вклад в изучение поселений и экономического взаимодействия раннесредневекового населения.

Редакция постаралась сделать так, чтобы публикуемые статьи объективно отражали состояние исследований независимо от личной позиции ученого. Однако это было сложно реализовать, и некоторые статьи содержали собственные субъективные мнения авторов (Wędzki 2004: 202). Сотрудничество только с польскими учеными привело к рассмотрению многих вопросов с узкой польской точки зрения, однако авторы старались помещать предмет своего исследования в более широкий сравнительный контекст (Wędzki 1993: 90).

Анализ «Словаря славянских древностей» через четверть века после его завершения показал, что труд положительно восприняли в научных кругах (Krandžalov 1960: 295). Его часто цитируют как в польских, так и в зарубежных публикациях по различным научным дисциплинам. Придание словарю междисциплинарности и размещение его на интернет-платформе значительно увеличило круг читателей, что способствует объединению исследований по ранней истории, географии, культуре и обычаям древних славян ${ }^{2}$.

2 См.: https://rcin.org.pl/dlibra/publication/6769/slownik-starozytnoscislowianskich-encyklopedyczny-zarys-kultury-slowian-od-czasow-najdaw niejszych-t-1. 
Словарь стал широко используемым энциклопедическим изданием международного масштаба. В 2008 г. Отдел истории Института славистики Польской Академии наук опубликовал новое двухтомное издание «Ранние славяне. Справочник по истории и литературе» (Wczesna 2008). Оно содержит важнейшую информацию о формировании славянских народов и государств, биографиях выдающихся славистов, изучающих славянские древности, а также обширную библиографию по этой теме до 2005 г. включительно. В настоящее время редактируется английская версия справочника.

Эти публикации являются частью 55-летней работы Отдела истории Института славистики Польской Академии наук и расширяют знания о древних славянах.

\section{Литература}

Batowski 1945 - Batowski H. Słownik starożytności słowiańskich // Odrodzenie. Vol. 29. 1945. P. 8.

Batowski 1954 - Batowski H. List H. Batowskiego do Redakcji Przeglądu Zachodniego // Przegląd Zachodni. Vol. 1, no. 10. 1954. S. 612-613.

Krandžalov 1960 - Krandžalov D. Dvě vyznamná iniciativní díla polske slavistiky // Acta Universitatis Palackinae Olomucensis. Historica. Vol. 1. 1960. P. 295.

Słownik 1934 - Słownik starożytności słowiańskich: zeszyt próbny = Dictionnaire des antiquités slaves: fascicule d'épreuve / [kom. red. F. Bujak]; Federacja Towarzystw Historycznych Europy Wschodniej. Warszawa: Kasa im. Mianowskiego, 1934.

Wczesna 2008 - Wczesna Słowiańszczyzna. Przewodnik po dziejach i literaturze przedmiotu. T. 1: A - Z; T. 2: Bibliografia. Warszawa: Slawistyczny Ośrodek Wydawniczy, 2008.

Wędzki 1993 - Wędzki A. Blaski i cienie pierwszej polskiej encyklopedii slawistycznej. Uwagi na marginesie zamknięcia prac nad Słownikiem starożytności słowiańskich // Nauka Polska. 1993. T. 6. S. 89-94.

Wędzki 2004 - Wędzki A. Słownik starożytności słowiańskich z perspektywy pół wieku // 50 lat slawistyki w Polskiej Akademii Nauk (19542004): księga jubileuszowa Instytutu Slawistyki PAN / kom. red. pod kier. K. Handke. Warszawa: Slawistyczny Ośrodek Wydawniczy, 2004. S. 199-215. 


\section{The History of Polish "The Dictionary of Slavic Antiquities" in a Quarter of a Century since its Inception}

"The Dictionary of Slavic Antiquities" is an encyclopaedic summary of the current state of knowledge about the history and culture of the Slavs on a global scale. The first attempts to create this dictionary were undertaken in 1927 but only its post-war concept was fully successful. This article presents the course of work on the dictionary, the stages of its creation, as well as the specifics of the entire publishing process.

DOI: $10.31168 / 0459-6.31$

M. Китанова (София, България)

\section{Българската етнолингистична лексикография през новото хилядолетие}

Основна дейност на членовете на Секцията за етнолингвистика към Института за български език «Профр. Л. Андрейчин» е развиване на етнолингвистичната лексикография. В последните двайсет години са изработени четири речника - три тематични и един азбучен.

\section{Тематични речници}

1. Тематичен речник на термините от народния календар / П. Легурска, М. Китанова. София: Академично издателство «Проф. Марин Дринов», 2008. 150 с. ISBN 978954-322-079-3.

2. Човешкият живот - раждане, сватба, погребение: Тематичен речник на семейната обредност / П. Легурска, Н. Павлова, М. Китанова. София: Академично издателство «Профр. Марин Дринов», 2012. 166 с. ISBN 9789543225484. 